\title{
Effects of Particle Size and Composite Composition of Durian Peels and Banana Midribs' as Reinforcement Components on Resin-Based Brake Pad Performance
}

DOI:10.36909/jer.ASSEEE.16029

Asep Bayu Dani Nandiyanto*, Alma Tyara Simbara, Gabriela Chelvina Santiuly Girsang

Departemen Pendidikan Kimia, Universitas Pendidikan Indonesia, Jl. Dr. Setiabudhi No. 229, Bandung, 40154, Indonesia.

*Email: nandiyanto@upi.edu; Corresponding Author.

\begin{abstract}
This study aims to determine the effect of particle size and material composition on the performance of resin-based brake pads. Experiments were carried out by mixing $75 \%$ UPR with durian peel and banana midribs fibers using ratios of $1 / 1,3 / 2$, and $2 / 3$ at particle sizes of 104 and $250 \mu \mathrm{m}$. The experimental results shows that decreasing the particle size improves the mechanical properties of brake pads, but gives a high wear value and a low coefficient of friction. In addition, an increase in the percentage of banana midrib fibers as a whole provides better brake pad performance. The results of the comparison between commercial-based brake pads confirm that agricultural waste is potential as an alternative to friction materials in brake pads. Brake pad with a fiber ratio of $2 / 3104 \mu \mathrm{m}$ had highest values of hardness, wear and friction coefficient, namely $20.33 \mathrm{~N} / \mathrm{cm}^{3}, 2.02 \times 10^{-4} \mathrm{~g} / \mathrm{s} \mathrm{mm}^{2}$, and 0.2465 . while the $1 / 1250$ $\mu \mathrm{m}$ and $3 / 2250 \mu \mathrm{m}$ had the lowest coefficient values and compressive strength of 0.1195 and $9.14 \mathrm{~N} / \mathrm{cm}^{3}$. This study demonstrates the use of biomass waste as an alternative to friction material to overcome the dangerous problem of using asbestos in brake pads.
\end{abstract}

Key words: brake pad; particle size; durian peels; banana midribs; unsaturated polyester resin.

\section{INTRODUCTION}

The composition of brake pad material generally consists of $60 \%$ of asbestos, creating problems in polluting environment and health issues. Many studies have developed alternative 
materials to replace asbestos in brake pads by utilizing natural fiber-reinforced biocomposites (Dwiyati et al., 2017) (See Table 1).

Durian has a distinctive skin with a weight percentage reaching 60-75\% (Rahman, 2018). This skin contains $50-60 \%$ of cellulose, $5 \%$ of lignin, and $5 \%$ of low starch. Therefore, durian peel can be used as a mixture of raw materials for various compress products (Tausif et al., 2017). Banana midrib has a composition of $60-65 \%$ of cellulose, $6-8 \%$ of hemicellulose, 5 $10 \%$ of lignin, and 10-15\% of water (Vaisanen et al., 2016). The lignin content of these two natural ingredients can make brake pads have optimal quality according to ASTM (Effendy et al., 2017). The use of resin is effective to allow the process under room temperature and pressure.

Natural fiber reinforced polymer biocomposite technology is currently in great demand because it is environmentally friendly, low production costs, and high availability of materials (Mallick, 2007). Several studies have been carried out on the manufacture of brake pads using durian peel or banana midribs fibers. Table 1 shows a state of the art research on the manufacture of resin-based brake pads.

Table 1. The State of The Art

\begin{tabular}{|c|c|c|c|c|}
\hline References & Material & Methode & Result & $\begin{array}{l}\text { Differences } \\
\text { With This } \\
\text { Study }\end{array}$ \\
\hline $\begin{array}{l}\text { Masturi dkk., } \\
(2018)\end{array}$ & $\begin{array}{ll}\text { - } & \text { Durian rind } \\
& \text { fiber } \\
\text { - } & \mathrm{MgO} \\
\text { - } & \text { Teak leaves } \\
\text { - } & \text { Polyester resin }\end{array}$ & $\begin{array}{c}\text { Physical and } \\
\text { Chemical } \\
\text { treatment. }\end{array}$ & $\begin{array}{l}\text { Samples with a composition of } 40 \% \\
\text { durian rind fiber, } 10 \% \text { magnesium } \\
\text { oxide, } 40 \% \text { teak leaves, and } 10 \% \\
\text { polyester resin are identical to brake } \\
\text { pads that have been circulating in the } \\
\text { market and comply with SNI } 09-0143 \\
\text { standards. }\end{array}$ & $\begin{array}{l}\text { Using a } \\
\text { mixture of } \\
\text { raw materials } \\
\text { and different } \\
\text { test } \\
\text { parameters. }\end{array}$ \\
\hline $\begin{array}{ll}\text { Idris } & \text { dkk., } \\
(2015) & \end{array}$ & $\begin{array}{ll}\text { - } & \text { Banana peels } \\
\text { - } & \text { Phenolic resin }\end{array}$ & $\begin{array}{l}\text { Carbonization and } \\
\text { reduction of } \\
\text { particle size. }\end{array}$ & $\begin{array}{l}\text { The compressive strength, hardness } \\
\text { and density of the resulting samples } \\
\text { were seen to increase with the } \\
\text { addition of the resin percentage, while } \\
\text { the oil immersion, water immersion, } \\
\text { wear rate and burn percentage } \\
\text { decreased along with the increase in } \\
\text { resin percentage. }\end{array}$ & $\begin{array}{lr}\text { Using } & \text { a } \\
\text { different } & \text { type } \\
\text { of } & \text { resin } \\
\text { binder. } & \end{array}$ \\
\hline Prayoga (2016) & $\begin{array}{ll}\text { - } & \text { Banana midrib } \\
\text { - } & \text { Grafhite } \\
\text { - } & \text { Barite } \\
\text { - } & \mathrm{CaCO}_{3} \\
\text { - } & \text { Epoxy resin }\end{array}$ & Sintering & $\begin{array}{l}\text { Brake pads using banana tree frond } \\
\text { fibers are suitable for use because } \\
\text { they have a wear rate close to that of } \\
\text { the factory brake pads, namely } 2.5 \mathrm{x} \\
10^{-6} \text { grams } / \mathrm{mm}^{2} \text {. }\end{array}$ & $\begin{array}{l}\text { Using } \\
\text { different raw } \\
\text { materials, } \\
\text { methods and } \\
\text { types } \\
\text { polymers. of }\end{array}$ \\
\hline Bashir & - $\quad$ Banana Peel & Pressure & Banana stalk powder can be used & Using \\
\hline
\end{tabular}




\begin{tabular}{|c|c|c|c|c|}
\hline (2015) & $\begin{array}{ll}\text { - } & \mathrm{CaCO}_{3} \\
\text { - } & \mathrm{CaOH}_{2} \\
\text { - } & \mathrm{Graphite} \\
\text { - } & \mathrm{Sb}_{2} \mathrm{~S}_{3} \\
\text { - } & \mathrm{MoS}_{2} \\
\text { - } & \mathrm{Al}_{2} \mathrm{O}_{3} \\
\text { - } & \mathrm{MgO} \\
\text { - } & \mathrm{SiC} \\
\text { - } & \mathrm{Steel} \mathrm{Wool} \\
\text { - } & \mathrm{PAN} \mathrm{fiber} \\
\text { - } & \mathrm{CaSiO}_{3}\end{array}$ & Moulding & $\begin{array}{l}\text { effectively to increase the binding } \\
\text { capacity of phenolic resins at higher } \\
\text { temperatures. }\end{array}$ & $\begin{array}{lr}\text { different } & \text { resin } \\
\text { types and } \\
\text { methods. }\end{array}$ \\
\hline $\begin{array}{l}\text { Ossia } \quad \text { dkk., } \\
(2020)\end{array}$ & $\begin{array}{ll}\text { - } & \text { Coconut shells } \\
\text { - } & \text { CaCO3 } \\
\text { - } & \text { Carbon } \\
\text { - } & \text { Phenol } \\
& \text { formaldehyde } \\
& \text { resin } \\
\text { - } & \text { MEKP catalyst } \\
\end{array}$ & $\begin{array}{l}\text { Moulding and } \\
\text { curing process }\end{array}$ & $\begin{array}{l}\text { The brake Pad has better thermal } \\
\text { conductivity and properties at particle } \\
\text { sizes below } 90 \mu \mathrm{m}\end{array}$ & $\begin{array}{ll}\text { Using } & \text { a } \\
\text { different } & \\
\text { materials } & \end{array}$ \\
\hline
\end{tabular}

However, until now, research on the use of banana midribs or durian peels as raw material for brake pad has not been carried out. In fact, wastes' potential in Indonesia is very large. This study aims to determine the effect of particle size and composition of brake pad based on resin. Its performance was analyzed using a test of wear rate, mass loss, coefficient of friction, heat resistance, compressive strength, and puncture strength. The method used is non-pressure, occurs at room temperature, and involves a polymerization reaction. It is expected that the crosslink polyester reaction with the MEKP catalyst can occur when the resin has interacted with the fibers in the molding to harden. It is also expected to discover the brake pads quality.

\section{METHOD}

\section{Brake Pad Production}

Brake pads are made by collecting durian peels' and banana midribs' waste in Tasikmalaya, Indonesia. This ingredients are cut into small pieces and dried in the sun for 3 days. To get a specific size, the particle of durian peels and banana midribs that have been ground are put into a mesh filter according to ASTM D1921. Pan sieves with special mesh sizes of 60 and 150 were used to obtain 104 and $250 \mu \mathrm{m}$ particles of durian peel and banana midrib, respectively. Brake pads are made using two variations in size (104 and $250 \mu \mathrm{m})$ where each size has three ratios of durian skin fiber/banana stalk, namely $1 / 1,3 / 2$, and 2/3. 
75\% UPR was added as matrix and 10\% MEKP by weight of UPR was added as a catalyst. The mixture was poured into a silicone mold $(2.4 \times 2.3 \times 1.8 \mathrm{~cm})$ and dried in room (at room temperature) for 3 days. Prior to testing, all brake pads are sanded to remove the resin effect on the surface.

\section{Mechanical Properties Test}

The mechanical properties of brake pads are obtained from testing the compressive strength and puncture strength. The Screw Mount Test Instrument (Model I ALX-J, China) equipped with a digital force gauge (Model HP-500, Serial, No H5001909262) was used for the compression test. While the puncture strength test was carried out using the Shore Durometer instrument (Shore A Hardness, In size, China). Density can be calculated using Eq. (1):

$\rho=\frac{m}{V}$

\section{Friction Test}

In this test, the brake pad is rubbed against sandpaper (80 grit) for 20 minutes at a speed of $25 \mathrm{~cm} / \mathrm{s}$. Its mass is recorded every 2 minutes. Its wear rate $(\mathrm{M})$ can be calculated using Eq. (2) (Sukrawan et al, 2019):

$M=\frac{\left(M_{a}-M_{b}\right)}{t \times A}$

where $M_{a}$ is the initial mass of the brake pad $(\mathrm{g}), M_{b}$ is the mass of the final brake pad $(\mathrm{g}), \mathrm{t}$ is the test time, and $\mathrm{A}$ is the friction cross-sectional area $\left(\mathrm{mm}^{2}\right)$. The ratio of the $\mathrm{f}(\mathrm{N})$ friction force to the normal force $\mathrm{N}(\mathrm{N})$ is the coefficient of friction $(\mu)$ which can be expressed in Eq. (3) (Burris and Sawyer, 2009):

$\mu=f / N$

\section{RESULTS AND DISCUSSION}

Proposal Chemical Polymerization Reaction during the Formation of UPR-Based Brake Pad 
The concept of making UPR matrix brake pads uses the involvement of polymerization at room temperature which can bind and compact the fiber components. This polymerization mechanism involves the addition of free radicals that attack the double bonds in the UPR chain (Bartoli, 2019). Figure 3-6 shows the curing reaction mechanism in the UPR chain. The overall reaction mechanism is as follows (Nadilah, 2003):

a. Peroxide catalyst (MEKP) breaks down as free radical tert-butyldioxy-O (RO) which acts as an initiator (will attack the double bond on UPR).

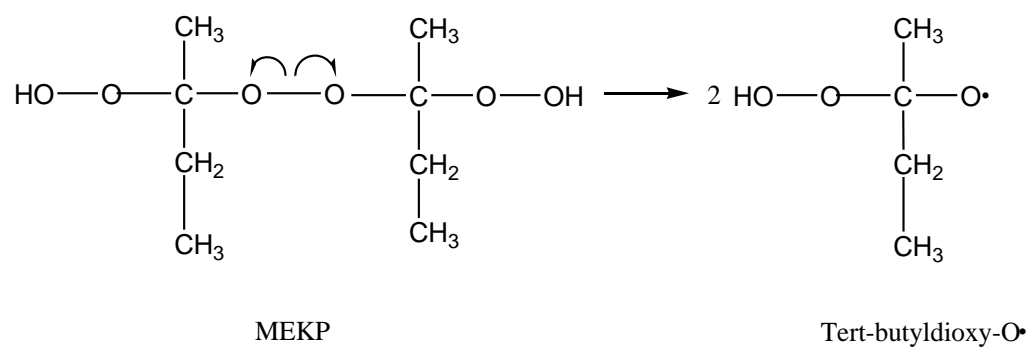

Figure 3. The reaction of free radical formation from the MEKP catalyst

b. Free radical attack (RO) will result in the formation of unpaired electrons in the UPR chain.

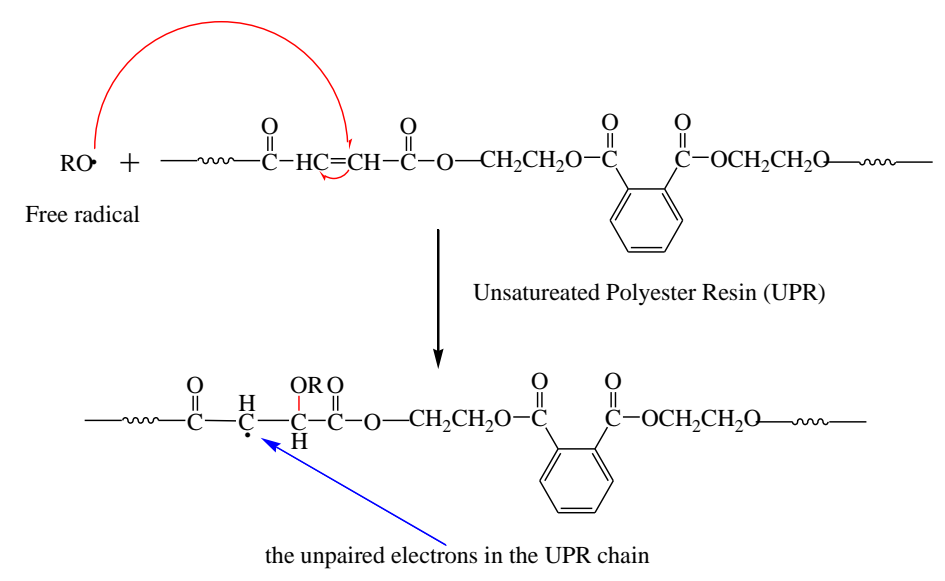

Figure 4. Tert-butyldioxy-O free radical (RO) attack on the UPR chain

c. The unpaired electrons on the UPR will attack the double bond in styrene, thus forming a crosslink bond. This crosslink bond results in the formation of unpaired electrons in styrene. 


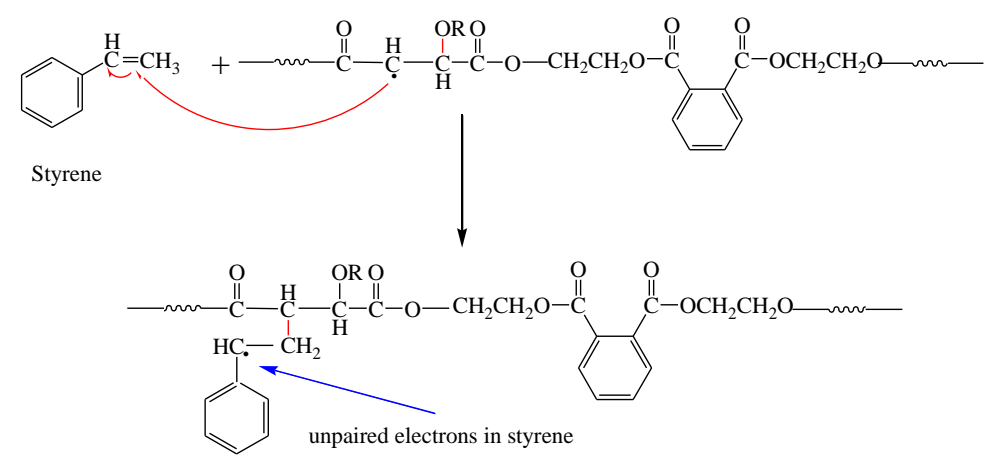

Figure 5. The reaction of crosslink formation between UPR and styrene molecules

d. The unpaired electrons will then attack other UPR molecules, forming new free radicals that will attack other styrene molecules. This reaction continuous until the UPR molecule hardens (cured).

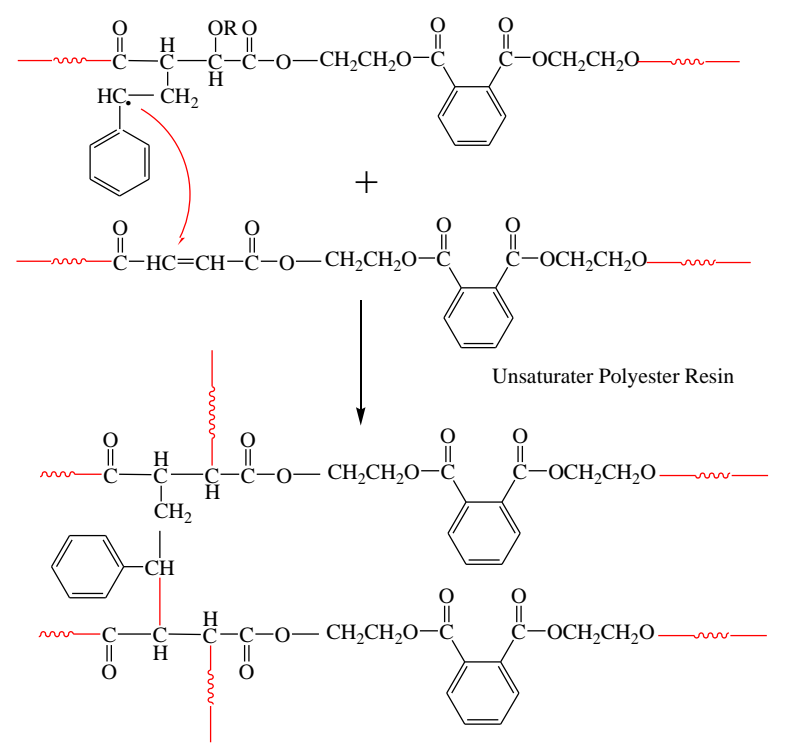

Figure 6. UPR chain polymerization and curing reactions.

\section{Physical Appearance of Brake Pad}

The surface view of brake pad was observed under a microscope and is presented in Table 3. Based on the observations, brake pads with a pore size of $250 \mu \mathrm{m}$ had larger and larger pores compared to $104 \mu \mathrm{m}$ (see table 5). Brake pads with a smaller particle size result in fewer pores with a finer structure.

Table 3. Surface View of Brake Pad

\begin{tabular}{|l|l|}
\hline Particle Size & Fiber Composition Ratio \\
\hline
\end{tabular}




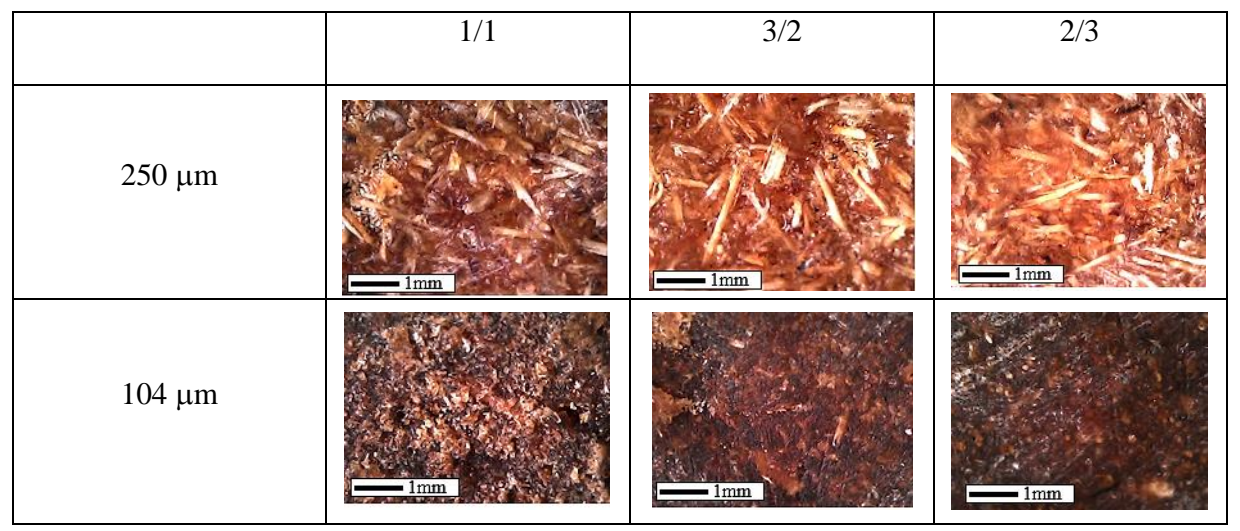

Table 4 shows a microscope image of the pores in the brake pad matrix which can support the texture profile analysis. It's shows that the $1 / 1$ composition of durian peels and banana midribs produced smaller and fewer pores. The particle size also greatly affects the pores of the brake pads. Brake pad with large particle sizes have larger pores as well since there are less bonds between the materials thus creating more space. With larger pores, the performance of the brake pad is decreasing, and vice versa. This happens because the outer bond between the materials is higher and makes the performance of the brake pads increase.

Table

4.

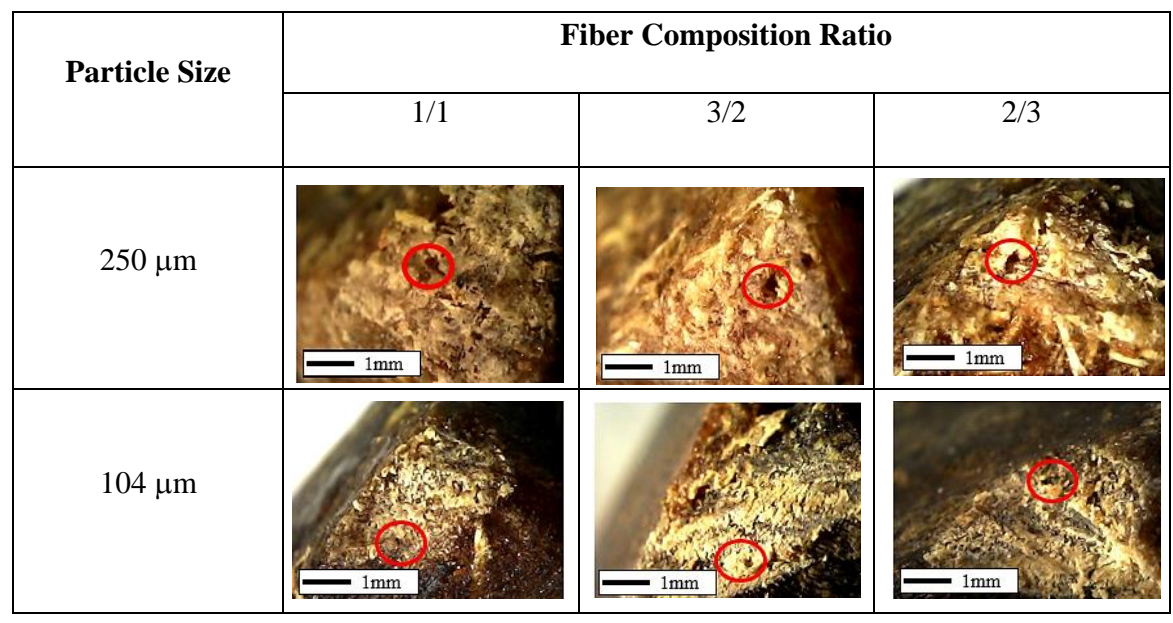

Microscope image of the pores in the brake pad matrix 


\section{Mechanical Properties}

Figure 8 and 9 shows the results of the compression test for brake pad. In Figure 8, it can be seen that $104 \mu \mathrm{m}$; ratio $2 / 3$ has the greatest compressive resistance, while the $250 \mu \mathrm{m}$; ratio $1 / 1$ has the smallest compressive resistance. Meanwhile, in Figure 9 it can be seen that the highest compressive strength value is at $104 \mu \mathrm{m}$; ratio $2 / 3$ and the lowest is at $250 \mu \mathrm{m}$; ratio $3 / 2$. Brake pads that have a low level of hardness can be caused by the low bond between the constituents, so that when pressed, the stress distribution will increases and spread to all parts where the part that is not too bonded will be deformed first. Thereby, it it can be understood here that the hardness of brake pad is also impacted by the particle size and composition of the constituent materials (Athif, 2018).

Table 5 shows the results of the brake pads compression test. Smaller numbers on the scale indicates a high indentation tolerance. From the table, it can be seen that the puncture force in brake pad increases in conjunction with decreasing particle size. Brake pad with $104 \mu \mathrm{m}$; ratio 2/3 has the greatest puncture strength, while $250 \mu \mathrm{m}$ : ratio $1 / 1$ has the smallest puncture strength. The size and number of pores in the material correlate with the particle size of the fibers. The larger particle size can trap air during the mixing process which creates pores, thereby increasing the crack path and stress intensity which makes brake pads susceptible to pressure and indentation (Rezanezhad et al, 2019). This is reinforced by the correlation between particle size and bulk density, where in the table it can be seen that the smaller the particle size, the greater the bulk density value. This also makes it has higher density, less 
pores and hard because the particle size and distribution affect the bulk density value (Tausif et al., 2017).

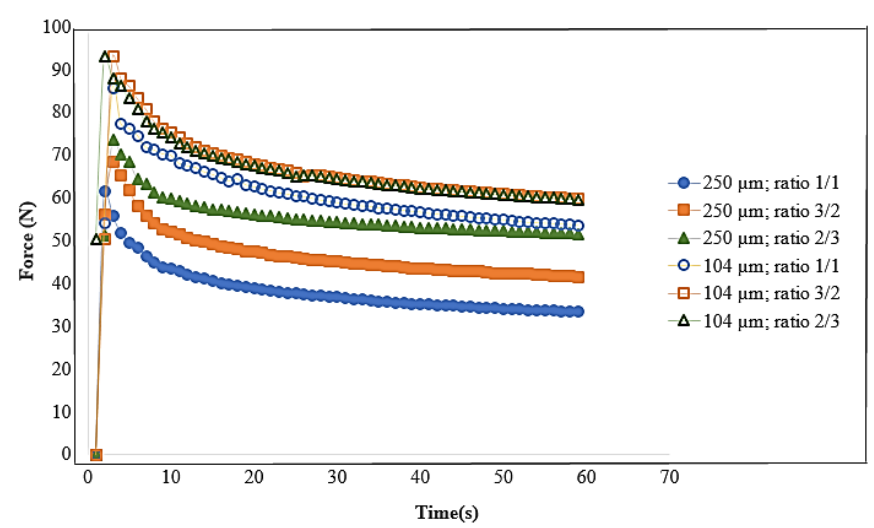

Figure 8. Compressive Test Results

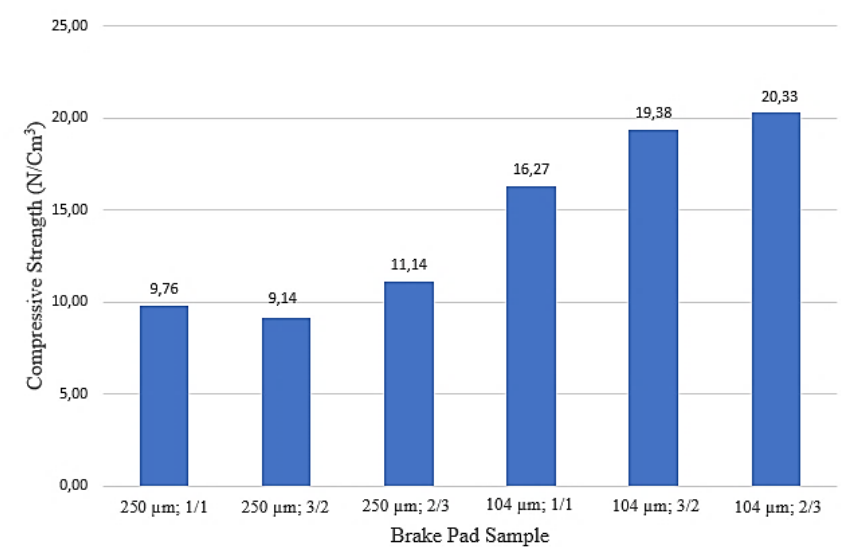

Figure 9. Compressive Strength Result

\begin{tabular}{|c|c|c|c|}
\hline Sample & $\begin{array}{c}\text { Durometer Shore } \\
\text { Hardness Scale }\end{array}$ & $\begin{array}{c}\text { Average Size of Pore } \\
(\mu \mathrm{m})\end{array}$ & Bulk density $\left(\mathrm{g} / \mathrm{cm}^{3}\right)$ \\
\hline $250 \mu \mathrm{m} ;$ ratio 1/1 & 80.56 & 335 & 3.0168 \\
\hline $250 \mu \mathrm{m} ;$ ratio 3/2 & 84.39 & 531 & 3,1953 \\
\hline $250 \mu \mathrm{m} ;$ ratio 2/3 & 88.00 & 628 & 3.0200 \\
\hline $104 \mu \mathrm{m} ;$ ratio 1/1 & 90.94 & 191 & 3.4665 \\
\hline $104 \mu \mathrm{m} ;$ ratio 3/2 & 93.00 & 306 & 3.3716 \\
\hline $104 \mu \mathrm{m} ;$ ratio 2/3 & 95.56 & 317 & 3.5759 \\
\hline
\end{tabular}

Table 5. Puncture Strength and Bulk Density Results

\section{Friction Properties}

Figure 10 and Table 6 show the results of the friction test which includes the level of mass loss, wear and friction coefficient of brake pad. The brake pad mass change is caused by 
repeated contact between the brake pad surface with sandpaper which in turn will take some of the material on the surface of the brake pads and cause mass loss.

The mass loss rate of all brake pads in this study was almost the same, only it can be seen that at larger particle sizes, the value of mass loss was smaller as in the $250 \mu \mathrm{m}$ ratio $3 / 2$ brake pad. This indicates that the wear rate of brake pads measuring $250 \mu \mathrm{m}$ is better than $104 \mu \mathrm{m}$. This is inversely related to the hardness data because the extent of the particle-matrix interface interaction at a smaller particle size allows small particles on the surface of the brake pad to escape, and vice versa (Saravanan et al, 2013).

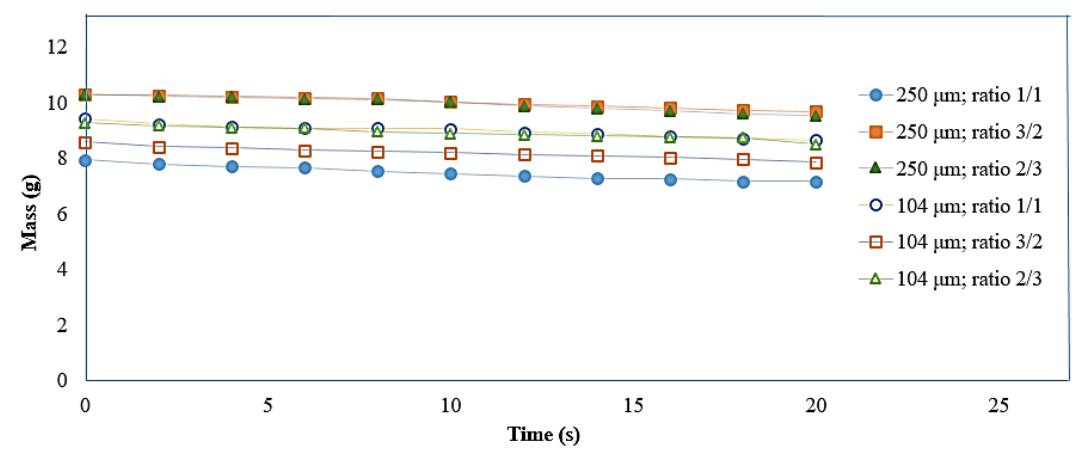

Figure 10. Loss of brake pad mass prepared as a function of time

The particle size and fiber composition also affect the friction coefficient. The friction coefficient of the material area depends on the smooth or rough surface of the brake pad. From the table, it can be seen that brake pads with a larger particle size have a higher friction coefficient. This occurs because the large particles are more difficult to remove during the friction test. Therefore, brake pads with a particle size of $104 \mu \mathrm{m}$ have a lower coefficient of friction than $250 \mu \mathrm{m}$. The difference in fiber composition affects the variation in the value of the friction coefficient. The higher the fiber composition, the higher the friction coefficient value so that it is more resistant to water disturbances (Suhadirman and Mukmin, 2017).

Table 6. Loss of mass, wear rate and coefficient of friction of the prepared brake pads

\begin{tabular}{|c|c|c|c|c|c|c|c|}
\hline Sample & $\mathrm{M}_{\mathrm{a}}(\mathrm{g})$ & $\begin{array}{c}\mathrm{M}_{\mathrm{b}} \\
(\mathrm{g})\end{array}$ & $\begin{array}{c}\text { Mass loss rate } \\
(\mathrm{g} / \mathrm{min})\end{array}$ & $\mathrm{t}(\mathrm{s})$ & $\mathrm{A}\left(\mathrm{mm}^{2}\right)$ & $\mathrm{M}\left(\mathrm{g} / \mathrm{s} . \mathrm{mm}^{2}\right)$ & $\begin{array}{c}\text { Friction } \\
\text { coefficient }\end{array}$ \\
\hline $250 \mu \mathrm{m}$; ratio $1 / 1$ & 7.95 & 7.17 & $0,039 \pm 0,266$ & 1200 & 3.6 & $1.81 \times 10^{-4}$ & 0.1195 \\
\hline
\end{tabular}




\begin{tabular}{|c|c|c|c|c|c|c|c|}
\hline $250 \mu \mathrm{m}$; ratio 3/2 & 10.30 & 9.69 & $0,031 \pm 0,220$ & 1200 & 4.14 & $1.23 \times 10^{-4}$ & 0.3204 \\
\hline $250 \mu \mathrm{m}$; ratio 2/3 & 10.31 & 9.54 & $0,039 \pm 0,268$ & 1200 & 4.14 & $1.55 \times 10^{-4}$ & 0.3210 \\
\hline $104 \mu \mathrm{m}$; ratio 1/1 & 9.43 & 8.65 & $0,039 \pm 0,233$ & 1200 & 3.36 & $1.93 \times 10^{-4}$ & 0.2577 \\
\hline $104 \mu \mathrm{m}$; ratio 3/2 & 8.59 & 7.87 & $0,036 \pm 0,212$ & 1200 & 3.08 & $1.95 \times 10^{-4}$ & 0.1851 \\
\hline $104 \mu \mathrm{m}$; ratio 2/3 & 9.29 & 8.51 & $0,039 \pm 0,224$ & 1200 & 3.22 & $2.02 \times 10^{-4}$ & 0.2465 \\
\hline
\end{tabular}

Figure 10 shows the comparison of the mass loss rate during the friction test between the $250 \mu \mathrm{m}$; ratio $2 / 3$ brake pads and conventional brake pads. Brake pads from $250 \mu \mathrm{m}$; ratio $2 / 3$ was chosen because it has the best performance at a particle size of $250 \mu \mathrm{m}$. From the graph, it can be seen that the mass loss rate is insignificant.

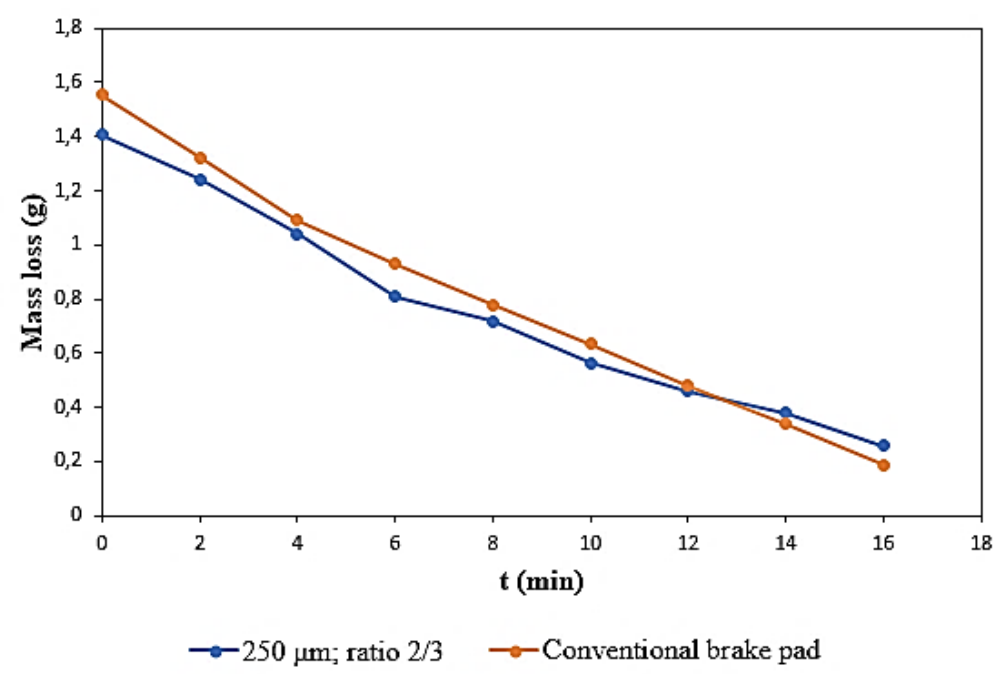

Figure 10. Comparison of the rate of mass loss of $250 \mu \mathrm{m}$; ratio $2 / 3$ with conventional brake pads using a $2 \times 0.4 \mathrm{~cm}$ friction test contact area

Table 4 show the comparison of the wear rate and friction coefficient of $250 \mu \mathrm{m}$; ratio $2 / 3$ brake pads with conventional brake pads. It can be seen that $250 \mu \mathrm{m}$; ratio $2 / 3$ brake pads has a better wear rate with a lower friction coefficient value of $10 \%$ compared to conventional brake pads. Its result indicates that durian peels and banana midribs have the potential to be used as reinforcing fibers in the manufacture of non-asbestos brake pads.

Table 7. Comparison the level of mass loss and friction coefficient of $250 \mu \mathrm{m}$; ratio $2 / 3$ brake pad with conventional brake pads. Where $M_{a}$ is the initial mass, $M_{b}$ is the final mass, $t$ is the friction time, $\mathrm{A}$ is the contact area of the friction test, and $\mathrm{M}$ is the wear rate. 


\begin{tabular}{|c|c|c|c|c|c|c|c|}
\hline Sample & $\mathrm{M}_{\mathrm{a}}(\mathrm{g})$ & $\mathrm{M}_{\mathrm{b}}(\mathrm{g})$ & $\begin{array}{c}\text { Mass loss rate } \\
(\mathrm{g} / \mathrm{min})\end{array}$ & $\mathrm{t}(\mathrm{s})$ & $\begin{array}{c}\mathrm{A} \\
\left(\mathrm{mm}^{2}\right)\end{array}$ & $\begin{array}{c}\mathrm{M}\left(\times 10^{-6}\right. \\
\left.\mathrm{g} / \mathrm{s}^{-6} \mathrm{~mm}^{2}\right)\end{array}$ & Friction coefficient \\
\hline $250 \mu \mathrm{m}$; ratio 2/3 & 1.405 & 0.258 & $0.063 \pm 0.069$ & 60 & 81 & 1.48 & 0.1832 \\
\hline $\begin{array}{c}\text { Conventional brake } \\
\mathrm{pad}\end{array}$ & 1.555 & 0.187 & $0.076 \pm 0.067$ & 60 & 85 & 1.68 & 0.2099 \\
\hline
\end{tabular}

\section{CONCLUSION}

The particle size of the UPR matrix brake pad affects the mechanical and frictional properties of the brake pad. Smaller particles can increase the hardness of the brake pad resulting in mechanical properties. However, it has a high wear rate with a low coefficient of friction. Overall, increasing the banana midrib fiber composition can improve the brake pad performance. Of all brake pads from $250 \mu \mathrm{m}$; ratio $2 / 3$ had the best performance. Although the wear rate is high, it is not significantly different from the others. The comparison result between brake pads made in this study with conventional brake pads also show that the friction material which is reinforced with durian peel and banana midribs has the potential to be used as environmentally friendly brake pads.

\section{REFERENCES}

Aminur, Hasbi, M. \& Gunawan, Y. 2015. Proses pembuatan biokomposit polimer serat untuk aplikasi kampas rem. Seminar Nasional Sains dan Teknologi. 1-7.

Anbunathan, P. E., Perumal, G., \& Senthilkumar, N. 2019. Characterization and wear studies on non-asbestos organic fiber reinforced low metallic friction composites. International Journal of Mechanical and Production Engineering Research and Development. 9: 133-143.

Athif, M. A., \& Ihsan. 2018. Uji kuat tekan dan keausan bahan kampas rem dari komposisi tempurung kemiri dan serat bambu. JFT. 5 (2): 29-38.

Bartoli, M., Rosi, L., \& Frediani, M. 2019. Synthesis and aplication of unsaturated polyester composites. Unsaturated Polyester Resins, 579-598.

Bashir, M., Shadid, S. S., \& Bashir, O. 2015. Friction and wear behavior of disc brake pad material using banana peel powder. Int. J. Res. Eng. Technol. 4 (2): 650-659. 
Burris, D. L., \& Sawyer, W. G. 2009. Addressing practical challenges of low friction coefficient measurements. Tribology letters. 35 (1): 17-23.

Dagwa, I. M., \& Ibhadode, A. O. A. 2005. Design and manufacture of experimental brake pad test rig. Nigerian Journal of Engineering Research and Development. 4 (3): 15-24.

De la Caba, K., Guerrero, P., Eceiza, A., \& Mondragon, I. 1996. Kinetic and rheological studies of an unsaturated polyester cured with different catalyst amounts. Polymer, 37: 275280.

Dwiyati, S. T., Kholil, A., \& Fickri, W. (2017). Pengaruh penambahan karbon pada karakteristik kampas rem komposit serbuk kayu. J. Konversi Energi dan Manufaktur UNJ. $2(2): 108-114$.

Feng, J., Wang, Y., Yi, X., Yang, W., \& He, X. 2016. Phenolics from durian exert pronounced no inhibitory and antioxidant activities. J. Agric. Food Chem. 64 (21): 42734279.

Gurunath, P. V., \& Bijwe, J. 2006. Friction and wear studies on brake-pad material based on newly developed resin. Wear. 263: 1212-1219.

Idris, U. D., Aigbodion, V. S., Abubakar, I. J., \& Nwoye, C. I. 2015. Eco-friendly asbestos free brake-pad: using banana peels. J. King Saud Unive. - Eng. Sci. 27 (2): 185-192.

Joseph, A., Albert, L. S., Baba, N. M., Anayimi, L. A. R., \& Modupe, O. A. 2020. Tribological properties of friction materials developed from non-asbestos materials using response surface methodology. International Journal Engineering Material and Manufacture. 5 (2): 40-49.

Joseph, A., Albert, L. S., Baba, N. M., Anayimi, L. A. R., \& Salawu, A. A. 2019. Effect of particle size distribution on the properties of natural based composite. International Journal Engineering Material and Manufacture. 4 (4): 170-177.

Kamal, M., \& Sourour, S. 1973. Kinetics and thermal characterization of thermoset cure. Polym. Eng. Sci. 13: 59-64.

Karthikeyan, S. S., Balakrishnan, E., Meganathan, S., Balachander, M., \& 
Ponshanmugakumar, A. 2019. Elemental analysis of brake pad using natural fibres. Material today: proceedings. 16: 1067-1074.

Kiswiranti, D. 2007. Pemanfaatan Serbuk Tempurung Kelapa Sebagai Alternatif Serat Penguat Bahan Friksi Non-asbes Pada Kampas Rem Sepeda Motor. Semarang: UNNS.

Kliger, H. S., \& Barker, E. R. 1984. A comparative Study of The Corrosion Resistance of Carbon and Glass Fibers, 39th Annual Conference of The Reinforced Plastics/Composites Institute, The Society of the Plastic Industry.

Mallick, P. K. 2017. Fiber Reinforced Composites Materials Manufacturing and Design 3rd Edition. United State: CRC Press Taylor \& Francis Group.

Masthura. 2019. Analisis fisis dan laju pembakaran briket bioarang dari bahan pelepah pisang. J. Islam. Sci. Technol. 5 (1): 58-66.

Masturi, S. Effendy, A. Gelu, H. Hammam, \& F. Fianti. 2018. Analysis of the mechanical properties brake canvas with basic ingredients of th durian fruit skin and teak leaves. J. Bahan Alam Terbarukan. 7 (2): 149-155.

Nadilah, S., Winursito, I., Wahyuni, S., Budiasih, S., \& Christiana. 2003. Poliester tak jenuh sebagai bahan baku pembuatan helm pengaman. Majalah Kulit, Karet, dan Plastik. 19 (1): $25-31$.

Ossia, C. V., Big-Alabo, A., \& Ekpruke, E. O. 2020. Effect of grain size on the physicomechanical properties. Advances in Manufacturing Science and Technology Effect. 44 (4): 135-144.

Parker, E. E. 1959. Mod. Plastics. 36: 135. June.

Prayoga, A. 2016. Penggunaan serat pelepah pohon pisang sebagai bahan alternatif dalam pembuatan kampas rem tromol sepeda motor (non asbes). J. Tek. Mesin Ubl. 3 (2): 1-6.

Primaningtyas, W. E., Sakura, R. R., Suheni., Biqi, A., \& Handoyo, C. 2018. Sintesis komposit kampas rem bebas asbes berpenguat serbuk kulit singkong. Jurnal Rekayasa Energi Manufaktur. 3 (2): 91-95.

Qurohman, M. T., \& Syarifudin. 2016. Analisa beban pengereman terhadap kualitas kampas 
rem tromol mobil dengan metode ogoshi. Jurnal Matematika.19 (1): 8-12.

Rahman, S. 2018. Teknologi Pengolahan Tepung dan Pati Biji-Bijian. Yogyakarta: CV Budi Utama.

Rezanezhad, M., Lajevardi, S. A., \& Karimpouli, S. 2019. Effects of pore-crack relative location on crack propagation in porous media using XFEM method. Theoretical and Applied Fracture Mechanics. 103: 102241

Saravanan, S. D., Senthilkumar, M., \& Shankar, S. 2013. Effect of particle size on tribological behavior of rice husk ash-reinforced aluminum alloy ( $\mathrm{AlSi}_{10} \mathrm{Mg}$ ) matrix composites. Tribology transactions. 56 (6): 1156-1167.

Sari, N. H. 2019. Teknologi Papan Komposit Diperkuat Serat Kulit Jagung. Yogyakarta: CV Budi Utama.

Suhadirman \& Mukmin, S. 2017. Analisa keausan kampas rem non asbes terbuat dari komposit polimer serbuk padi dan tempurung kelapa. J. Inovtek Polbeng. 7 (2): 210-214.

Sukrawan, Y., Hamdani, A., \& Mardani, S. A. 2019. Effect of bamboo weight faction on mechanical properties in non-asbestos composite of motorcycle brake pad. Materials Physics \& Mechanics. 42 (3).

Tausif, M., Pliakas, A., O'Haire, T., Goswami, P., \& Russel, S. J. 2017. Mechanical propoerties of nonwoven reinforced thermoplastic polyurethane composites. Materials (Basel). 10 (6): 1-13.

Väisänen, T., Haapala, A., Lappalainen, R., \& Tomppo, L. 2017. Utilization of agricurtural and forest industry waste and residues in natural fiber-polymer composites: a review. Waste Management. 54 (2): 210-214.

Wicaksono, R. B., Ranto., \& Estriyanto, Y. 2005. Kaji eksperimental performansi pengereman kampas rem serat bonggol jagung sebagai bahan altenatif kampas rem mobil. Jurnal Ilmiah Pendidikan Teknik Mesin. 4 (3): 1-10. 